\title{
DO EATING HABITS OF THE POPULATION LIVING IN ROMA SETTLEMENTS DIFFER FROM THOSE OF THE MAJORITY POPULATION IN SLOVAKIA?
}

\author{
Emília Hijová1 ${ }^{1}$ Andrea Madarasová Gecková2, Ingrid Babinskáa; HepaMeta Team* \\ ${ }^{1}$ Department of Experimental Medicine, Faculty of Medicine, P. J. Šafárik University in Košice, Košice, Slovakia \\ ${ }^{2}$ Health Psychology Unit, Department of Public Health, Faculty of Medicine, P. J. Šafárik University in Košice, Košice, Slovakia
}

\begin{abstract}
SUMMARY
Living in Roma settlements is associated with worse health in comparison with the majority population; this might be partially explained by socioeconomic disadvantages as well as cultural differences, including lifestyle. Eating habits represent an important part of lifestyle closely related to primary causes of morbidity and mortality, such as cardiovascular diseases, metabolic diseases or cancers. The eating habits of the population living in Roma settlements in comparison with those of the majority population were explored using the cross-sectional epidemiological HepaMeta study conducted in 2011. A representative sample of Roma ( $n=452$, mean age $=34.7 ; 35.2 \%$ men) and non-Roma ( $n=403$, mean age $=33.5 ; 45.9 \%$ men) aged $18-55$ years living in the Košice region were asked about breakfasting and recent consumption of fruits, vegetables, dairy products, meat products, meat, farinaceous dishes, and soft drinks. A logistic regression model was used separately for male and female participants. The population living in Roma settlements reported the recent consumption of fruit, vegetables and dairy products significantly less frequently in comparison with the majority population. Moreover, Roma females, in comparison with non-Roma females, reported significantly more frequently the consumption of meat and soft drinks. No differences were found between Roma and non-Roma in the consumption of meat products and farinaceous dishes. The population living in Roma settlements reported more frequently unhealthy eating habits in comparison with the majority population; this might contribute to worse health status of this population. The differences might be attributed to cultural differences between ethnic as well as socioeconomic groups, reduced availability of certain food items due to segregation or poverty and lower health literacy.
\end{abstract}

Key words: Roma settlements, eating habits, health

Address for correspondence: E. Hijová, Department of Experimental Medicine, Faculty of Medicine, P. J. Šafárik University in Košice, Tr. SNP 1, 04011 Košice, Slovakia. E-mail: hijova@pobox.sk

\section{INTRODUCTION}

There are 8 to 12 million Roma living worldwide (1), with approximately 5.2 million Roma living in Central and Eastern Europe (2). Slovakia is among countries with the highest share of Roma population: it is estimated that about 430,000 Roma live in Slovakia, which represents $8 \%$ of the Slovak population (3-5). Moreover, a considerable part of this population is living in settlements located in the eastern and southern part of Slovakia $(2,4)$. Living in Roma settlements indicates an accumulation of socioeconomic disadvantages like segregation, poor housing, overcrowding, limited access to drinking water, and a lack of sewage systems, and these communities experience generational poverty, a high prevalence of long-term unemployment, a low educational level and high risk of discrimination, violence, and usury $(2-4,6,7)$. The health status of most of the Roma population is worse than that of the non-Roma population living in Slovakia $(8,9)$. These findings have also been validated abroad (10-12). In particular the prevalence of obesity, type 2 diabetes mellitus, metabolic syndromes and cardiovascular diseases is high in the Roma population (13-17). Differences in health status between the Roma population and the majority population might be at-

*HepaMeta Team members are listed in Appendix tributed to differences in living conditions, different access to goods and services and the extent of poverty; cultural differences, mainly differences in health-related behaviour and health literacy; differences in psycho-social conditions, e.g. the health consequences of discrimination-related stress, social exclusion, material and financial deprivation, and low socioeconomic position; and cumulative disadvantage from early childhood (11, 18-21). Eating habits and nutrition in particular play a critical role in the prevention of non-communicable diseases and may differ in the culturelly different settings of Roma settlements. Dietary factors such as low consumption of fruit and vegetables and a diet high in fat (particularly saturated fats) and salt may cause, directly or through risk factors such as blood lipids, blood pressure or blood glucose, overweight and obesity (22-24). This kind of diet was found to be associated with low socioeconomic groups (25), to which the population living in Roma settlements generally belongs.

The aim of this study is to explore differences in eating habits between the population living in Roma settlements and the majority population in Slovakia.

\section{MATERIALS AND METHODS}

Data from the cross-sectional population-based HepaMeta study conducted in Slovakia in 2011 were used. This project aimed 
to map the prevalence of viral hepatitis $\mathrm{B} / \mathrm{C}$ and metabolic syndrome in the population living in separated and segregated Roma settlements and to compare it with the occurrence of the same health indicators in the majority population considering selected risk and protective factors of these health indicators. This study is described in details elsewhere $(26,27)$. A representative sample of Roma ( $\mathrm{n}=452$, mean age $=34.7 ; 35.2 \%$ men) and non-Roma ( $n=403$, mean age $=33.5 ; 45.9 \%$ men) aged $18-55$ years living in the Košice region were asked about breakfasting and recent consumption of fruits, vegetables, dairy products, meat products, meat, farinaceous dishes, and soft drinks.

Eating habits were measured by asking respondents the question: "Do you breakfast regularly, i.e., at least 4 times per week?” and "Did you eat yesterday and today?” Fruit - apple, banana, orange, or other raw fruit; vegetables - tomatoes, green pepper, lettuce, or other raw vegetables; dairy products - milk, yoghurt, cheese, or other dairy products; meat products - salami, sausage, ham, or other meat products; meat - schnitzel, roast chicken, steak, or other meat; dishes from flour - pasta, noodles, dumplings, pancakes, or other farinaceous foods; soft drinks - cola, lemonade or other soft drinks. Possible responses were yes/no. Days after Sundays as well as days when welfare benefits are received were excluded from the data collection schedule.

The differences in eating habits between the population living in Roma settlements and the majority population in Slovakia were analysed using logistic models separately for males and females. The analyses were performed with IBM SPSS Statistics 20.

\section{RESULTS}

The final sample comprised 452 Roma (mean age $=34.47$; $\mathrm{SD}=9.16 ; 35.2 \%$ men) and 403 (mean age =33.47; $\mathrm{SD}=7.41$; $45.9 \%$ men) non-Roma respondents. Results obtained from a representative sample of male and female respondents of both the Roma and majority populations are summarised in Table 1 . Nearly three-quarters of respondents reported eating breakfast regularly, and no statistically significant differences between Roma and non-Roma males or females were confirmed. Reported recent consumption of fruits was nearly two-times lower among Roma respondents living in Roma settlements in comparison with nonRoma (OR/CI, males: 0.56/0.36-0.88, females: 0.59/0.40-0.86).
Recent consumption of fruits like apple, banana, orange, or other raw fruit was reported by $46.4 \%$ of males and $57.2 \%$ of females living in Roma settlements, but $60.5 \%$ of males and $69.6 \%$ of females from the majority population. The differences in vegetable consumption are even greater. Reported recent consumption of vegetable (tomatoes, green pepper, lettuce, or other raw vegetables) was more than three-times lower among respondents living in Roma settlements in comparison with non-Roma (OR/ CI, males: 0.29/0.18-0.47, females: 0.30/0.20-0.46). Recent consumption of vegetables was reported by $49.3 \%$ of males and $53.7 \%$ of females living in Roma settlements, contrary to $77.3 \%$ of males and $79.3 \%$ of females in the majority population. The biggest differences were found in the consumption of milk, yoghurt, cheese, or other dairy products. Reported recent consumption of dairy products was six-times lower among Roma males in comparison with non-Roma males (OR/CI: 0.27/0.16-0.46) and more than eight-times lower among Roma females in comparison with non-Roma females (OR/CI: 0.12/0.07-0.21). While $81.8 \%$ of males and $92.5 \%$ of females from the majority population reported recent consumption of dairy products, only $55.1 \%$ of males and $59.7 \%$ of females living in Roma settlements did so. Roma males and females do not differ from their counterparts in the majority population in the recent consumption of salami, sausage, ham, or other meat products. Recent consumption of meat products was reported by more than $80 \%$ of males and more than $75 \%$ of females. More than $70 \%$ of males living in Roma settlements as well as from the majority reported the recent consumption of meat (schnitzel, roast chicken, steak, or other meat), but there is no statistical difference between them. However, more than $65 \%$ of Roma females, compared to $54 \%$ of non-Roma females (OR/CI: 1.62/1.11-2.37), reported the consumption of meat the day before the data collection. No differences between Roma and non-Roma were found in the recent consumption of pasta, noodles, dumplings, pancakes, or other farinaceous foods, which were reported by $70 \%$ of Roma males and females and more than $60 \%$ of non-Roma males and females. Similarly, no difference between Roma and non-Roma males was found in the consumption of soft drinks: $74.2 \%$ of Roma males and $67.9 \%$ of non-Roma males reported recent consumption of cola, lemonade or other soft drinks. On the other hand, $69.7 \%$ of Roma females compared to only $46.8 \%$ of non-Roma females reported recent consumption of soft drinks.

Table 1. Eating habits of the population living in Roma settlements in comparison with the majority population (prevalence, OR, Cl)

\begin{tabular}{|c|c|c|c|c|c|c|}
\hline & \multicolumn{3}{|c|}{ Male } & \multicolumn{3}{|c|}{ Female } \\
\hline & $\begin{array}{c}\text { Roma } \\
(\mathrm{N}=159) \\
\mathrm{n}(\%)\end{array}$ & $\begin{array}{c}\text { non-Roma } \\
(\mathrm{N}=185) \\
\mathrm{n}(\%)\end{array}$ & OR (95\% Cl) & $\begin{array}{c}\text { Roma } \\
(\mathrm{N}=293) \\
\mathrm{n}(\%)\end{array}$ & $\begin{array}{c}\text { non-Roma } \\
(\mathrm{N}=218) \\
\mathrm{n}(\%)\end{array}$ & OR (95\% Cl) \\
\hline Breakfast & $118(74.2)$ & $136(73.5)$ & $0.97(0.60-1.59)$ & $208(71.0)$ & $161(73.9)$ & $0.79(0.53-1.19)$ \\
\hline Fruits & $70(46.4)$ & $98(60.5)$ & $0,56(0.36-0.88)$ * & $162(57.2)$ & $135(69.6)$ & $0.59(0.40-0.86)$ ** \\
\hline Vegetables & 73 (49.3) & $126(77.3)$ & $0.29(0.18-0.47)^{\star \star \star}$ & $152(53.7)$ & $157(79.3)$ & $0.30(0.20-0.46)^{* * *}$ \\
\hline Dairy products & 81 (55.1) & 135 (81.8) & $0.27(0.16-0.46)^{\star \star \star}$ & $169(59.7)$ & $186(92.5)$ & $0.12(0.07-0.21)$ *** \\
\hline Meat products & $123(80.4)$ & $135(83.3)$ & $0.82(0.46-1.46)$ & $222(78.4)$ & $150(76.1)$ & $0.56(0.74-1.76)$ \\
\hline Meat & $111(73.0)$ & $116(72.0)$ & $1.05(0.64-1.73)$ & $181(65.1)$ & $98(53.6)$ & $1.62(1.11-2.37)$ * \\
\hline Farinaceous dishes & $104(70.3)$ & $93(62.4)$ & $1.42(0.88-2.31)$ & $195(69.1)$ & $111(60.7)$ & $1.45(0.99-2.15)$ \\
\hline Soft drinks & $115(74.2)$ & $108(67.9)$ & $1.36(0.83-2.22)$ & $198(69.7)$ & $88(46.8)$ & $2.62(1.79-3.83)$ *** \\
\hline
\end{tabular}

${ }^{*} \mathrm{p}<0.05,{ }^{* *} \mathrm{p}<0.01,{ }^{* * *} \mathrm{p}<0.001$ 


\section{DISCUSSION}

The population living in Roma settlements in comparison with the majority population reported less frequently the recent consumption of fruits, vegetables and dairy products, and among females more frequently the recent consumption of meat and soft drinks. No differences were found in regular breakfasting, recent consumption of meat products and farinaceous dishes.

Regular breakfasting has a relatively high prevalence in the majority population as well as the population in Roma settlements (over 70\%), which is in accordance with findings of some epidemiological (28) and anthropological studies $(29,30)$ conducted in populations in Roma settlements. Only about $5 \%$ of respondents among children and adults usually omitted breakfast (28). Belák reported on breakfasting of bread with meat products, soup or warmed leftover food from the previous day as a regular part of the day in the observed Roma community, while an actual feeling of hunger seems to be the only reason to join eating in community (29). Breakfast is recommended as a part of healthy diet, and breakfast consumers tend to have higher micro and macro nutrient intakes and lower BMI than those who skip breakfast (31, 32).

Lower consumption of fruits and vegetables among Roma in comparison with non-Roma was also confirmed in the works of Ostrihoňová and Bérešová (16), Popper et al. (28) and Kačala et al. (33). The lower prevalence of fresh fruit and vegetables in the Roma diet is usually attributed to financial stringency and poverty (30). Fruits and vegetables contribute to cardiovascular health through the variety of phytonutrients, potassium, folic acid, and fibre they contain (33). Daily intake of fresh fruits and vegetables (including berries, green leafy and cruciferous vegetables and legumes) in adequate quantities (400-500 g per day) is recommended to reduce the risk of coronary heart disease, stroke, high blood pressure, colorectal cancer, and to improve bowel function and contribute to better management of diabetes $(34,35)$.

Lower consumption of dairy product among Roma in comparison with non-Roma was also confirmed by Ostrihoňová and Bérešová (16). Dairy products are an important source of protein and certain vitamins and minerals, such as vitamin $D$, vitamin $A$ and vitamins B-12, B-6 and calcium (36). Use of dairy products, especially fermented products containing probiotics is important since probiotics have both local and general biomedical effects, inhibitory effect against pathogens, optimising effect on digestive processes, immunostimulative effect as well as anti-tumour and cholesterol-reducing activities (37).

About three-quarters of respondents, Roma as well as nonRoma, reported a relatively high prevalence of meat and meat products consumption and therefore the differences, particularly among males, were not significant. Several studies have previously reported preference for meat and meat products in the diet of Roma populations (16, 28, 29, 33). Meat and meat products consumption is usually the main source of fat intake in a diet, nevertheless, lowering the intake is usually recommended (34). Dietary intake of fats strongly influences the risk of cardiovascular diseases such as coronary heart disease and stroke through their effects on blood lipids, thrombosis, blood pressure, arterial (endothelial) function, arrhythmogenesis and inflammation (34).

Despite the fact that in our study the prevalence of farinaceous dishes was higher in the population living in Roma settlements in comparison with the majority population, no significant dif- ferences were confirmed. However, there are studies that have reported differences in the consumption of farinaceous dishes between Roma and non-Roma populations, 13.9\% of Roma contrary to only $4 \%$ of non-Roma reported high (nearly daily) consumption of farinaceous dishes (16). This dietary component belongs among traditional and favourite foods in Slovakia (38) due to its palatability and financial affordability as well.

The regular consumption of soft drinks represents a main source of high sugar intake, which might significantly contribute to overweight and obesity. Consumption of soft drinks is relatively high in Roma as well as non-Roma males (74.2\% vs. $67.9 \%)$, which might explain the lack of significant differences between them. Differences in the consumption of soft drinks among Roma and non-Roma women, e.g., the higher prevalence of soft drinks consumption among Roma women (69.7\%) in comparison with non-Roma women (46.8\%) might explain the higher prevalence of obesity among them (27). In contrast to these findings, a study by Belák reported water drinking in the observed Roma community and only sporadic consumption of soft drinks despite higher social status of the family (29). Women from majority population might be more aware of health-promoting campaigns, particularly those related to weight maintenance including drinking regime as a main part of the diet. At the same time they might experience fewer restrictions related to the availability of drinking water. Problematic access to drinking water in many Roma settlements - a probable cause of higher prevalence of water-borne diseases $(39,40)$ may lead to a preference of bottled drinks represented mainly by soft drinks. Soft drinks provide little nutritional benefit, by virtue of their high added-sugar content may be a key contributor to the epidemic of overweight and obesity and probably the risk of diabetes, fractures and dental caries as well (36, 41, 42). Drinking regime is an important part of a lifestyle, the consumption of drinks such as water, low-fat milk, and small quantities of fruit juice should be preferred (36).

Unhealthy eating habits might contribute to worse health status of Roma population in comparison with the majority population. These differences might be attributed to cultural differences related to ethnic as well as socioeconomic groups, lower availability of certain food due to segregation or poverty and health literacy $(25,43)$. Therefore, any strategy or intervention aimed at healthy nutritional habits has to tackle not only individual knowledge of nutrition and motivation but also structural factors like access to grocery stores, transportation, water supply, neighbourhood safety as well as the financial affordability of healthy foods for the particular population (25).

\section{Acknowledgement}

This project was partially supported by Roche Slovensko, s.r.o., and the Agency of the Slovak Ministry of Education for the Structural Funds of EU, project ITMS: 26220120058 (70\%).

\section{Conflict of Interests}

None declared

\section{APPENDIX}

HepaMeta Team: Peter Jarčuška, Andrea Madarasová Gecková, Mária Mareková, Daniel Pella, Leonard Siegfried, Pavol Jarčuška, 
Lýdia Pastvová, Ján Fedačko, Jana Kollárová, Peter Kolarčik, Daniela Bobáková, Zuzana Veselská, Ingrid Babinská, Sylvia Dražilová, Jaroslav Rosenberger, Ivan Schréter, Pavol Kristian, Eduard Veselíny, Martin Janičko, Ladislav Virág, Anna Birková, Marta Kmet’ová, Monika Halánová, Darina Petrášová, Katarína Cáriková, Viera Lovayová, Lucia Merkovská, Lucia Jedličková, Ivana Valková

\section{REFERENCES}

1. EURoma report: Roma and the structural funds. Madrid: Fundación Secretariado Gitano; 2010.

2. Filadelfiová J, Gerbery D, Škobla D. Report on the living conditions of Roma in Slovakia. Bratislava: UNDP, Regional Bureau for Europe; 2007.

3. Marcinčin A, Marcinčinová L'. Losses from Roma segregation - the key to integration is respect of diversity. Bratislava: Open Society Foundation; 2009.

4. Vašečka M, Džambazovič R. Socio-economic situation of Romanies in Slovakia as potential migrants and asylum seekers in EU member states. Bratislava: International Organization for Migration; 2000. (In Slovak.)

5. Vaňo B, Haviarová E. Roma population demographic trends. In: Vašečka M, editor. Čačipen pal o Roma. A global report on Roma in Slovakia. Bratislava: Inštitút pre verejné otázky; 2002. p. 475-502. (In Slovak.)

6. European Union Agency for Fundamental Rights. EU-MIDIS European Union minorities and discrimination survey [Internet]. European Union Agency for Fundamental Rights; 2009 [cited 2013 Aug 20]. Available from: http://fra.europa.eu/fraWebsite/eu-midis/index_en.htm.

7. Silva P, editor. Roma health mediators: successes and challenges. New York: Open Society Foundations; 2011.

8. Bertková I, Petrášová D. Morbidity as one of the parameters of the health state of Romany population. Slov Lek. 2004;14(11-12):332-4. (In Slovak.)

9. Ginter E, Krajcovicova-Kudlackova M, Kacala O, Kovacic V, Valachovicova M. Health status of Romanies (Gypsies) in the Slovak Republic and in the neighbouring countries. Bratisl Lek Listy. 2001;102(10):479-84.

10. Hajioff S, McKee M. The health of the Roma people: a review of the published literature. J Epidemiol Community Health. 2000 Nov;54(11):864-9.

11. Peters J, Parry GD, Van Cleemput P, Moore J, Cooper CL, Walters SJ. Health and use of health services: a comparison between Gypsies and Travellers and other ethnic groups. Ethn Health. 2009 Aug;14(4):359-77.

12. Vokó Z, Csépe P, Németh R, Kósa K, Kósa Z, Széles G, et al. Does socioeconomic status fully mediate the effect of ethnicity on the health of Roma people in Hungary? J Epidemiol Community Health. 2009 Jun;63(6):455-60.

13. Bartošovič I, Hegyi L. Romani health problems. Lek Obzor. 2010;59(4):156-61. (In Slovak.)

14. Ginter E, Havelková B, Krajčovičová-Kudláčková M, Baráková A, Hlava P. Differences in health status of different regions of Slovakia: 5. Roma population. Med Monitor. 2004;(4):10-2. (In Slovak.)

15. Vozarova de Courten B, de Courten M, Hanson RL, Zahorakova A, Egyenes HP, Tataranni PA, et al. Higher prevalence of type 2 diabetes, metabolic syndrome and cardiovascular diseases in gypsies than in nongypsies in Slovakia. Diabetes Res Clin Pract. 2003 Nov;62(2):95-103.

16. Ostrihoňová T, Bérešová J. Occurrence of metabolic syndrome and its risk factors amongst a selected group of Roma inhabitants. Hygiena. 2010;55(1):7-14. (In Slovak.)

17. Krajcovicova-Kudlackova M, Blazicek P, Spustova V, Valachovicova M, Ginter E. Cardiovascular risk factors in young Gypsy population. Bratisl Lek Listy. 2004;105(7-8):256-9.

18. Rosicova K, Madarasova Geckova A, van Dijk JP, Kollarova J, Rosic M, Groothoff JW. Regional socioeconomic indicators and ethnicity as predictors of regional infant mortality rate in Slovakia. Int J Public Health. 2011 Oct;56(5):523-31.

19. Bastos JL, Celeste RK, Faerstein E, Barros AJ. Racial discrimination and health: a systematic review of scales with a focus on their psychometric properties. Soc Sci Med. 2010 Apr;70(7):1091-9.

20. Dressler WW, Oths KS, Gravlee CC. Race and ethnicity in public health research: models to explain health disparities. Annu Rev Anthropol. 2005;34:231-52.

21. Wilkinson R, Marmot M, editors. Social determinants of health: the solid facts. Copenhagen: WHO Regional Office for Europe; 1998.
22. Hu FB, Willett WC. Optimal diets for prevention of coronary heart disease. JAMA. 2002 Nov 27;288(20):2569-78.

23. Grundy SM. Lipids, nutrition and coronary heart disease. In: Fuster V, Ross R, Topol EJ, editors. Atherosclerosis and coronary artery disease. Philadelphia: Lippincott - Raven; 1996. p. 45-68.

24. Mente A, de Koning L, Shannon HS, Anand SS. A systematic review of the evidence supporting a causal link between dietary factors and coronary heart disease. Arch Intern Med. 2009 Apr 13;169(7):659-69.

25. Darmon N, Drewnowski A. Does social class predict diet quality? Am J Clin Nutr. 2008 May;87(5):1107-17.

26. Madarasová Gecková A, Jarčuška P, Mareková M, Pella D, Siegfried L, Jarčuška P, et al.; HepaMeta Team. HepaMeta - Prevalence of hepatitis $\mathrm{B} / \mathrm{C}$ and metabolic syndrome in population living in separated and segregated Roma settlements: a methodology for a cross-sectional populationbased study using community-based approach. Cent Eur J Public Health. 2014 Mar;22 Suppl:S6-11.

27. Babinska I, Dankulincova Veselska Z, Bobakova D, Pella D, Panico S, Reijneveld SA, et al.; HEPA-META team. Is the cardiovascular risk profile of people living in Roma settlements worse in comparison with the majority population in Slovakia? Int J Public Health. 2013 Jun;58(3):417-25.

28. Popper M, Szeghy P, Šarkozy Š. Health and Roma community: analysis of the situation in Slovakia. Bratislava: Partners for Democratic Change Slovakia; 2009. (In Slovak.)

29. Belák A. Health through eyes of those excluded. A Medical-anthropological survey of Romani rural settlement in Central Slovakia [dissertation]. Prague: Charles University; 2005. (In Slovak.)

30. Davidova E, et al. Quality of life, life expectation, healthy life expectations and health determinants of Roma population in Czech and Slovak Republic: research report [CD-ROM]. České Budějovice: Jihočeská univerzita v Českých Budějovicích; 2010. (In Czech.)

31. Hoyland A, Dye L, Lawton CL. A systematic review of the effect of breakfast on the cognitive performance of children and adolescents. Nutr Res Rev. 2009 Dec;22(2):220-43.

32. Ruxton CHS, Kirk TR. Breakfast: a review of associations with measures of dietary intake, physiology and biochemistry. Br J Nutr. 1997 Aug;78(2):199-213.

33. Kačala O, Ginter E, Kovačič V, Krajčovičová-Kudláčková M, Valachovičová M. Comparison of nutrition Slovaks, Hungarians and Roma in ethnically mixed territory of Slovakia. Med Monitor. 2002;8(1):22-4.

34. World Health Organization. Diet, nutrition and the prevention of chronic diseases: report of a joint WHO/FAO expert consultation. WHO technical report series, no. 916. Geneva: WHO; 2003.

35. Sproston K, Mindell J, editors. Health survey for England 2004. Vol. 1. The health of minority ethnic groups. Leeds: Health \& Social Care Information Centre; 2006.

36. Malik VS, Schulze MB, Hu FB. Intake of sugar-sweetened beverages and weight gain: a systematic review. Am J Clin Nutr. 2006 Aug;84(2):274-88.

37. Bomba A, Brandeburová A, Ričanyová J, Strojný L, Chmelárová A, Szabadosová $\mathrm{V}$, et al. The role of probiotics and natural bioactive compounds in modulation of the common molecular pathways in pathogenesis of atherosclerosis and cancer. Biologia, 2012;67(1)1-13.

38. Markuš M. Folk diet. In: Podolák J, et al. The upper reaches of the river Cirocha: national history monograph of the inundation area. Košice: Východoslovenské vydavatel'stvo; 1985. (In Slovak.)

39. Monasta L, Andersson N, Ledogar RJ, Cockcroft A. Minority health and small numbers epidemiology: a case study of living conditions and the health of children in 5 foreign Romá camps in Italy. Am J Public Health. 2008 Nov;98(11):2035-41.

40. Dostal M, Topinka J, Sram RJ. Comparison of the health of Roma and non-Roma children living in the district of Teplice. Int J Public Health. 2010 Oct;55(5):435-41.

41. Schulze MB, Manson JE, Ludwig DS, Colditz GA, Stampfer MJ, Willett WC, et al. Sugar-sweetened beverages, weight gain, and incidence of type 2 diabetes in young and middle-aged women. JAMA. 2004 Aug 25;292(8):927-34.

42. Wyshak G. Teenaged girls, carbonated beverage consumption, and bone fractures. Arch Pediatr Adolesc Med. 2000 Jun;154(6):610-3.

43. Johnson M, Everson-Hock E, Jones R, Woods HB, Payne N, Goyder E. What are the barriers to primary prevention of type 2 diabetes in black and minority ethnic groups in the UK? A qualitative evidence synthesis. Diabetes Res Clin Pract. 2011 Aug;93(2):150-8. 